\title{
The SISAL database: a global resource to document oxygen and carbon isotope records from speleothems
}

Kamolphat Atsawawaranunt et al.

Correspondence to: Laia Comas-Bru (laia.comas-bru@ucdconnect.ie)

The copyright of individual parts of the supplement might differ from the CC BY 4.0 License. 
Figure S1: The structure of the SISAL database, showing individual tables (and their contents) and the nature of the relationships between them (where "many to one linkages" indicate that it is possible to have several entries in one table linked to a single entry in another table).

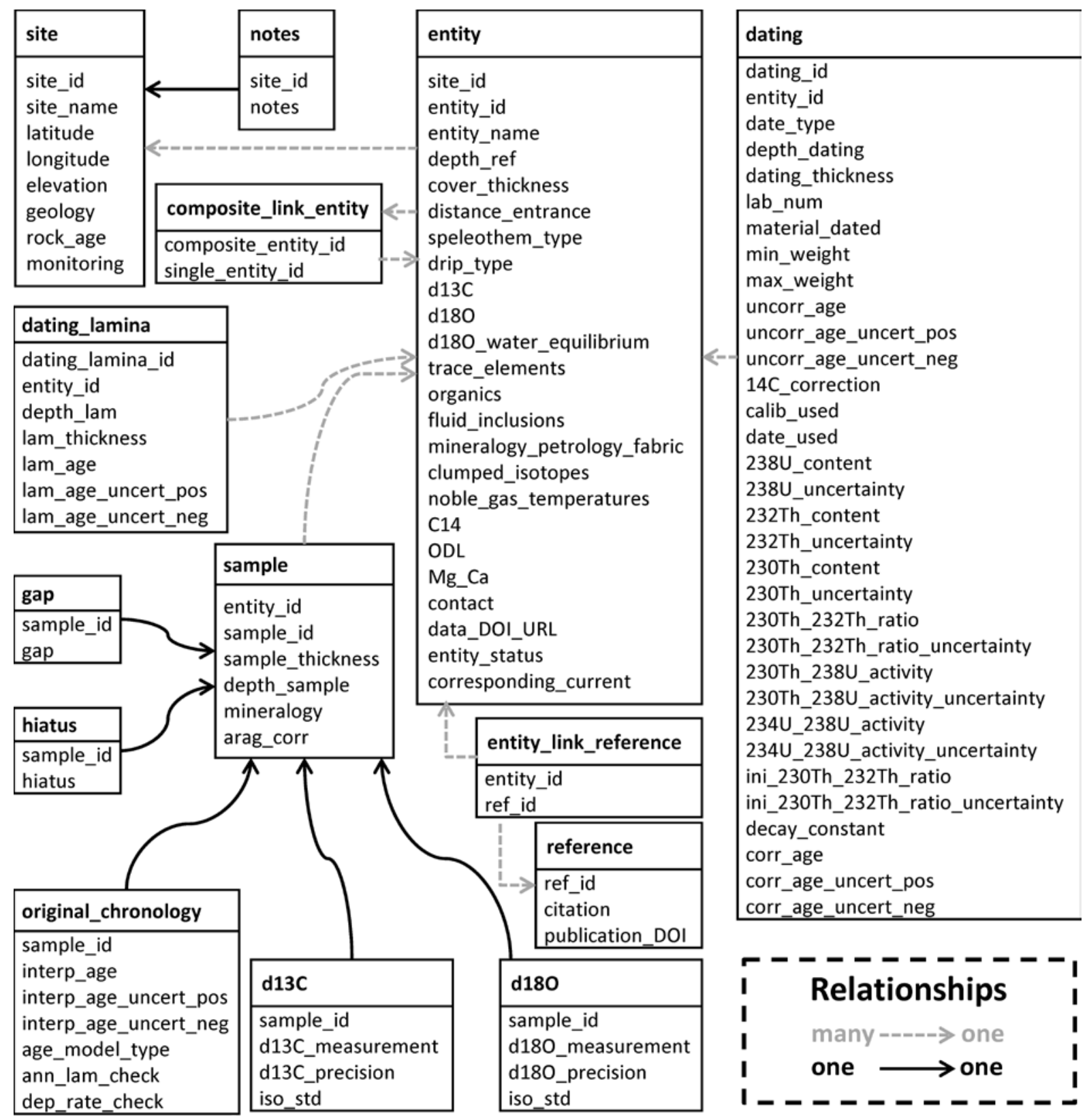


Table S1: Definition of pre-defined choice for all fields in the SISAL_v1 database

\begin{tabular}{|c|c|c|}
\hline Table name & Field & Lists \\
\hline d13C & iso_std & 'PDB', 'Vienna-PDB' \\
\hline $\mathrm{d} 18 \mathrm{O}$ & iso_std & 'PDB', 'Vienna-PDB' \\
\hline dating & date_type & $\begin{array}{l}\text { 'C14', 'MC-ICP-MS U/Th', 'ICP-MS U/Th Other', } \\
\text { 'Alpha U/Th', 'TIMS', 'U/Th unspecified', 'Cross- } \\
\text { dating', 'Multiple methods', ‘Event; hiatus', 'Event; } \\
\text { actively forming', 'Event; start of laminations', } \\
\text { 'Event; end of laminations', 'unknown' }\end{array}$ \\
\hline dating & material_dated & 'calcite’, ‘aragonite’, ‘organic’, ‘other’, ‘unknown’ \\
\hline dating & calib_used & $\begin{array}{l}\text { 'INTCAL13 NH', 'INTCAL13 SH', 'INTCAL13 } \\
\text { marine', 'INTCAL09', 'INTCAL09 marine’, } \\
\text { 'INTCAL04 NH', 'INTCAL04 SH', 'INTCAL98', } \\
\text { 'FAIRBANKS09', 'not calibrated', 'unknown' }\end{array}$ \\
\hline dating & date_used & 'yes', ‘no’, ‘unknown’ \\
\hline dating & decay_constant & $\begin{array}{l}\text { 'Cheng et al. 2000', 'Cheng et al. 2013', 'Edwards et } \\
\text { al. 1987', 'Ivanovich \& Harmon 1992', 'others', } \\
\text { 'unknown' }\end{array}$ \\
\hline entity & depth_ref & 'from top', ‘from base’, 'not applicable’ \\
\hline entity & speleothem_type & $\begin{array}{l}\text { ‘stalagmite', ‘composite', 'stalactite', ‘flowstone’, } \\
\text { 'unknown', 'other’ }\end{array}$ \\
\hline entity & drip_type & $\begin{array}{l}\text { 'seepage flow', 'seasonal drip’, 'fast flow', 'mixture', } \\
\text { 'unknown' }\end{array}$ \\
\hline entity & $\mathrm{d} 13 \mathrm{C}$ & 'yes’, ‘no', ‘unknown’ \\
\hline entity & $\mathrm{d} 18 \mathrm{O}$ & 'yes', 'no', ‘unknown' \\
\hline entity & d18O_water_equilibrium & 'yes', 'no', ‘unknown' \\
\hline entity & trace_elements & 'yes', 'no', ‘unknown' \\
\hline entity & organics & 'yes', 'no', ‘unknown' \\
\hline entity & fluid_inclusions & 'yes', 'no', ‘unknown' \\
\hline entity & mineralogy_petrology_fabric & 'yes', 'no', ‘unknown' \\
\hline entity & clumped_isotopes & ‘yes', ‘no’, ‘unknown’ \\
\hline entity & noble_gas_temperatures & 'yes', 'no', ‘unknown' \\
\hline entity & C14 & 'yes', 'no', ‘unknown' \\
\hline entity & ODL & 'yes', 'no', ‘unknown' \\
\hline entity & Mg_Ca & 'yes’, 'no', ‘unknown’ \\
\hline entity & entity_status & 'current', 'current partially modified', 'superseded' \\
\hline gap & gap & 'G' \\
\hline hiatus & hiatus & 'H' \\
\hline original_chronology & age_model_type & $\begin{array}{l}\text { 'linear', 'linear between dates', 'polynomial fit', } \\
\text { 'polynomial fit omitting outliers', 'Bayesian’, } \\
\text { 'Bayesian Bacon', 'Bayesian Bchron', 'StalAge', } \\
\text { 'StalAge and other', 'Clam', 'COPRA', 'OxCal', } \\
\text { 'combination of methods', 'unknown', 'other' }\end{array}$ \\
\hline original_chronology & ann_lam_check & $\begin{array}{l}\text { ‘14C peak', ‘14C slope', 'U/Th cycle’, 'trace element } \\
\text { cycle', 'assumed', 'not applicable', 'unknown' }\end{array}$ \\
\hline original_chronology & dep_rate_check & 'yes', 'no', 'assumed’, 'not applicable’, ‘unknown' \\
\hline sample & mineralogy & $\begin{array}{l}\text { 'calcite’, 'secondary calcite', 'aragonite', 'vaterite', } \\
\text { 'mixed', 'unknown’ }\end{array}$ \\
\hline
\end{tabular}




\begin{tabular}{|l|l|l|} 
sample & composite & 'yes', 'no', 'unknown' \\
\hline sample & arag_corr & 'yes', 'no', 'not applicable', 'unknown' \\
\hline site & geology & $\begin{array}{l}\text { 'limestone', 'dolomite', 'gypsum', 'magmatic', } \\
\text { 'marble', 'granite', 'mixed', 'other', 'unknown' }\end{array}$ \\
\hline \multirow{3}{*}{ site } & $\begin{array}{l}\text { 'Holocene', 'Pleistocene', 'Pliocene', 'Miocene', } \\
\text { 'Oligocene', 'Eocene', 'Palaeocene', 'Cretaceous', } \\
\text { 'Jurassic', 'Triassic', 'Permian', 'Carboniferous', } \\
\text { 'Devonian', 'Silurian', 'Ordovician', 'Cambrian', } \\
\text { 'Precambrian', 'unknown' }\end{array}$ \\
\hline site & rock_age & 'yes', 'no', 'unknown' \\
\hline
\end{tabular}

Table S2: Characteristics of the site table

\begin{tabular}{|c|c|c|c|}
\hline Field label & Definition & Format & Constraints \\
\hline site_id & $\begin{array}{l}\text { Unique identifier for each site, where a site is } \\
\text { defined as a cave or cave system }\end{array}$ & Numeric & Positive integer \\
\hline site_name & $\begin{array}{l}\text { Site name as given by original authors or as } \\
\text { defined by us where there was no unique name } \\
\text { given to the site }\end{array}$ & Text & None \\
\hline latitude & $\begin{array}{l}\text { Latitude of the cave site, given in decimal } \\
\text { degrees, where } \mathrm{N} \text { is positive and } \mathrm{S} \text { is negative }\end{array}$ & Numeric & None \\
\hline longitude & $\begin{array}{l}\text { Longitude of the cave site, given in decimal } \\
\text { degrees, } \mathrm{E} \text { is positive and } \mathrm{W} \text { is negative }\end{array}$ & Numeric & None \\
\hline elevation & $\begin{array}{l}\text { Elevation of the cave, in meters above sea level } \\
\text { (where negative values indicate elevations below } \\
\text { sea level) }\end{array}$ & Numeric & None \\
\hline geology & Description of the rock type & Text & $\begin{array}{l}\text { selected from } \\
\text { pre-defined list }\end{array}$ \\
\hline rock_age & Description of age of the rock & Text & $\begin{array}{l}\text { selected from } \\
\text { pre-defined list }\end{array}$ \\
\hline monitoring & $\begin{array}{l}\text { Indication of whether long-term monitoring of } \\
\text { cave conditions have been carried out }\end{array}$ & Text & $\begin{array}{l}\text { selected from } \\
\text { pre-defined list }\end{array}$ \\
\hline
\end{tabular}


Table S3: Characteristics of the entity table

\begin{tabular}{|c|c|c|c|}
\hline Field & Definition & Format & Constraints \\
\hline site_id & $\begin{array}{l}\text { Refers to the unique identifier for } \\
\text { each site (as given in site table) }\end{array}$ & Numeric & Positive integer \\
\hline entity_id & $\begin{array}{l}\text { Unique identifier for each entity, } \\
\text { where an entity is defined as a } \\
\text { speleothem or a speleothem } \\
\text { composite }\end{array}$ & Numeric & Positive integer \\
\hline entity_name & $\begin{array}{l}\text { Entity (speleothem) name as given } \\
\text { by the author }\end{array}$ & Text & None \\
\hline entity_status & $\begin{array}{l}\text { Status of the entity record, } \\
\text { specifically whether it is current, is } \\
\text { current but includes modifications } \\
\text { or additional information, or it has } \\
\text { been superseded by another record }\end{array}$ & Text & $\begin{array}{l}\text { selected from } \\
\text { pre-defined list }\end{array}$ \\
\hline corresponding_current & $\begin{array}{l}\text { This refers to the entity_id of the } \\
\text { record which replaces a } \\
\text { superseded record or to the } \\
\text { entity_id of other current records } \\
\text { that are linked to a current but } \\
\text { partially modified record. }\end{array}$ & Numeric & Positive integer \\
\hline depth_ref & $\begin{array}{l}\text { Indication of whether the reference } \\
\text { point is the top or base of the } \\
\text { speleothem }\end{array}$ & Text & $\begin{array}{l}\text { selected from } \\
\text { pre-defined list }\end{array}$ \\
\hline cover_thickness & $\begin{array}{l}\text { Thickness of overlying bedrock } \\
\text { above the speleothem (m) }\end{array}$ & Numeric & Positive decimal \\
\hline distance_entrance & $\begin{array}{l}\text { Distance of the speleothem from } \\
\text { the cave entrance (m) }\end{array}$ & Numeric & Positive decimal \\
\hline speleothem_type & Description of the speleothem type & Text & $\begin{array}{l}\text { selected from } \\
\text { pre-defined list }\end{array}$ \\
\hline drip_type & Description of the drip type & Text & $\begin{array}{l}\text { selected from } \\
\text { pre-defined list }\end{array}$ \\
\hline d13C & $\begin{array}{l}\text { Indication of whether } \delta^{13} \mathrm{C} \\
\text { measurements have been made of } \\
\text { the speleothem }\end{array}$ & Text & $\begin{array}{l}\text { selected from } \\
\text { pre-defined list }\end{array}$ \\
\hline $\mathrm{d} 18 \mathrm{O}$ & $\begin{array}{l}\text { Indication of whether } \delta^{18} \mathrm{O} \\
\text { measurements have been measured }\end{array}$ & Text & $\begin{array}{l}\text { selected from } \\
\text { pre-defined list }\end{array}$ \\
\hline d180_water_equilibrium & $\begin{array}{l}\text { Indication of whether studies } \\
\text { assessing if the speleothem is } \\
\text { precipitating in equilibrium with } \\
\text { dripwaters have been done }\end{array}$ & Text & $\begin{array}{l}\text { selected from } \\
\text { pre-defined list }\end{array}$ \\
\hline trace_elements & $\begin{array}{l}\text { Indication of whether trace } \\
\text { elements have been measured }\end{array}$ & Text & $\begin{array}{l}\text { selected from } \\
\text { pre-defined list }\end{array}$ \\
\hline organics & $\begin{array}{l}\text { Indication of whether organics } \\
\text { have been measured }\end{array}$ & Text & $\begin{array}{l}\text { selected from } \\
\text { pre-defined list }\end{array}$ \\
\hline fluid_inclusions & $\begin{array}{l}\text { Indication of whether fluid } \\
\text { inclusions have been measured }\end{array}$ & Text & $\begin{array}{l}\text { selected from } \\
\text { pre-defined list }\end{array}$ \\
\hline mineralogy_petrology_fabric & $\begin{array}{l}\text { Indication of whether fabric } \\
\text { measurements have been made }\end{array}$ & Text & $\begin{array}{l}\text { selected from } \\
\text { pre-defined list }\end{array}$ \\
\hline clumped_isotopes & $\begin{array}{l}\text { Indication of whether clumped } \\
\text { isotopes have been measured }\end{array}$ & Text & $\begin{array}{l}\text { selected from } \\
\text { pre-defined list }\end{array}$ \\
\hline noble_gas_temperatures & Indication of whether noble gases & Text & selected from \\
\hline
\end{tabular}




\begin{tabular}{|l|l|l|l|}
\hline & have been measured & & pre-defined list \\
\hline C14 & $\begin{array}{l}\text { Indication of whether }{ }^{14} \mathrm{C} \\
\text { measurements have been made }\end{array}$ & Text & $\begin{array}{l}\text { selected from } \\
\text { pre-defined list }\end{array}$ \\
\hline ODL & $\begin{array}{l}\text { Indication of whether the optical } \\
\text { density of luminosity } \\
\text { measurements have been made }\end{array}$ & Text & $\begin{array}{l}\text { selected from } \\
\text { pre-defined list }\end{array}$ \\
\hline Mg_Ca & $\begin{array}{l}\text { Indication of whether the Mg/Ca } \\
\text { ratio measurements have been } \\
\text { made }\end{array}$ & Text & $\begin{array}{l}\text { selected from } \\
\text { pre-defined list }\end{array}$ \\
\hline data_doi_url & $\begin{array}{l}\text { Name of the person who entered } \\
\text { the data into the workbook }\end{array}$ & Text & None \\
\hline & $\begin{array}{l}\text { Digital Object Identifier (DOI) of } \\
\text { the data or URL of the webpage } \\
\text { from which the data can be } \\
\text { obtained. }\end{array}$ & Text & None \\
\hline
\end{tabular}

Table S4: Characteristics of the sample table

\begin{tabular}{|l|l|l|l|}
\hline Field & Description & Format & Constraints \\
\hline entity_id & $\begin{array}{l}\text { Refers to the unique identifier for each } \\
\text { entity (as given in entity table) }\end{array}$ & Numeric & Positive integer \\
\hline sample_id & Unique identifier for the sample & Numeric & Positive integer \\
\hline sample_thickness & Thickness of the sample analysed (mm) & Numeric & Positive decimal \\
\hline depth_sample & Distance in mm from a reference point & Numeric & Positive decimal \\
\hline mineralogy & Description of the mineralogy of the sample & Text & $\begin{array}{l}\text { selected from } \\
\text { pre-defined list }\end{array}$ \\
\hline arag_corr & $\begin{array}{l}\text { Indication of whether the isotope } \\
\text { measurements have been corrected in } \\
\text { aragonite samples }\end{array}$ & Text & $\begin{array}{l}\text { selected from } \\
\text { pre-defined list }\end{array}$ \\
\hline
\end{tabular}


Table S5: Characteristics of the dating information table

\begin{tabular}{|c|c|c|c|}
\hline Field & Description & Format & Constraints \\
\hline dating_id & Unique identifier for each date & Numeric & Positive integer \\
\hline entity_id & $\begin{array}{l}\text { Refers to the unique identifier for each } \\
\text { entity (as given in entity table) }\end{array}$ & Numeric & Positive integer \\
\hline date_type & Description of the dating method used & Text & $\begin{array}{l}\text { selected from } \\
\text { pre-defined list }\end{array}$ \\
\hline depth_dating & Distance in mm from a reference point & Numeric & Positive decimal \\
\hline dating_thickness & Thickness of dated sample in mm & Numeric & Positive decimal \\
\hline lab_num & $\begin{array}{l}\text { The laboratory number of the dated } \\
\text { sample }\end{array}$ & Text & None \\
\hline material_dated & Mineralogy of the dated sample & Text & $\begin{array}{l}\text { selected from } \\
\text { pre-defined list }\end{array}$ \\
\hline min_weight & $\begin{array}{l}\text { Minimum weight of the dated sample } \\
\text { in mg }\end{array}$ & Numeric & Positive decimal \\
\hline max_weight & $\begin{array}{l}\text { Maximum weight of the dated sample } \\
\text { in mg }\end{array}$ & Numeric & Positive decimal \\
\hline uncorr_age & $\begin{array}{l}\text { Uncorrected age of the dated sample in } \\
\text { years }\end{array}$ & Numeric & None \\
\hline uncorr_age_uncert_pos & $\begin{array}{l}\text { Positive uncertainty of the uncorrected } \\
\text { age of the dated sample in years }\end{array}$ & Numeric & Positive decimal \\
\hline uncorr_age_uncert_neg & $\begin{array}{l}\text { Negative uncertainty of the } \\
\text { uncorrected age of the dated sample in } \\
\text { years }\end{array}$ & Numeric & Positive decimal \\
\hline 14C_correction & $\begin{array}{l}\text { Percentage dead carbon present in } \\
\text { dated sample }\end{array}$ & Numeric & Positive decimal \\
\hline calib_used & $\begin{array}{l}\text { Calibration method used to convert } \mathrm{C}^{14} \\
\text { dates to calendar years }\end{array}$ & Text & $\begin{array}{l}\text { selected from } \\
\text { pre-defined list }\end{array}$ \\
\hline date_used & $\begin{array}{l}\text { Indication of whether the date is used } \\
\text { in the original age model }\end{array}$ & Text & $\begin{array}{l}\text { selected from } \\
\text { pre-defined list }\end{array}$ \\
\hline 238U_content & ${ }^{238} \mathrm{U}$ content of the dated sample in $\mathrm{ppb}$ & Numeric & None \\
\hline 238U_uncertainty & $\begin{array}{l}{ }^{238} \mathrm{U} \text { 2-sigma uncertainty of dated } \\
\text { sample in ppb }\end{array}$ & Numeric & None \\
\hline 232Th_content & $\begin{array}{l}{ }^{232} \text { Th content of the dated sample in } \\
\text { ppt }\end{array}$ & Numeric & None \\
\hline 232Th_uncertainty & $\begin{array}{l}{ }^{232} \text { Th 2-sigma uncertainty of the dated } \\
\text { sample in ppt }\end{array}$ & Numeric & None \\
\hline 230Th_content & $\begin{array}{l}{ }^{230} \mathrm{Th} \text { content of the dated sample in } \\
\mathrm{ppt}\end{array}$ & Numeric & None \\
\hline 230Th_uncertainty & $\begin{array}{l}{ }^{230} \text { Th 2-sigma uncertainty of the dated } \\
\text { sample in ppt }\end{array}$ & Numeric & None \\
\hline 230Th_232Th_ratio & $\begin{array}{l}{ }^{230} \mathrm{Th} /{ }^{232} \mathrm{Th} \text { activity ratio of the dated } \\
\text { sample }\end{array}$ & Numeric & None \\
\hline $\begin{array}{l}\text { 230Th_232Th_ratio_un } \\
\text { certainty }\end{array}$ & $\begin{array}{l}{ }^{230} \mathrm{Th} /{ }^{232} \mathrm{Th} \text { activity ratio } 2 \text {-sigma } \\
\text { uncertainty of the dated sample }\end{array}$ & Numeric & None \\
\hline 230Th_238U_activity & $\begin{array}{l}{ }^{230} \mathrm{Th} /{ }^{238} \mathrm{U} \text { activity ratio of the dated } \\
\text { sample }\end{array}$ & Numeric & None \\
\hline $\begin{array}{l}\text { 230Th_238U_activity_ } \\
\text { uncertainty }\end{array}$ & $\begin{array}{l}{ }^{230} \mathrm{Th} /{ }^{238} \mathrm{U} \text { activity ratio } 2 \text {-sigma } \\
\text { uncertainty of the dated sample }\end{array}$ & Numeric & None \\
\hline 234U_238U_activity & $\begin{array}{l}{ }^{234} \mathrm{U} /{ }^{238} \mathrm{U} \text { activity ratio of the dated } \\
\text { sample }\end{array}$ & Numeric & None \\
\hline 234U_238U_activity_u & ${ }^{234} \mathrm{U} /{ }^{238} \mathrm{U}$ activity ratio 2-sigma & Numeric & None \\
\hline
\end{tabular}




\begin{tabular}{|l|l|l|l|}
\hline ncertainty & uncertainty of the dated sample & & \\
\hline ini_230Th_232Th_ratio & $\begin{array}{l}\text { Initial }{ }^{230} \mathrm{Th} /{ }^{232} \mathrm{Th} \text { activity ratio for the } \\
\text { detrital correction }\end{array}$ & Numeric & None \\
\hline $\begin{array}{l}\text { ini_230Th_232Th_ratio } \\
\text { _uncertainty }\end{array}$ & $\begin{array}{l}\text { Initial }{ }^{230} \mathrm{Th} /{ }^{232} \text { Th activity ratio } \\
\text { uncertainty for the detrital correction }\end{array}$ & Numeric & None \\
\hline decay_constant & $\begin{array}{l}\text { Description of the half-life used for } \\
\text { 230} \text { Th and }{ }^{234} \text { U for U/Th samples }\end{array}$ & Text & $\begin{array}{l}\text { selected from } \\
\text { pre-defined list }\end{array}$ \\
\hline corr_age & $\begin{array}{l}\text { Corrected age of the dated sample in } \\
\text { years }\end{array}$ & Numeric & None \\
\hline corr_age_uncert_pos & $\begin{array}{l}\text { Positive uncertainty of corrected age of } \\
\text { the dated sample in years }\end{array}$ & Numeric & Positive decimal \\
\hline corr_age_uncert_neg & $\begin{array}{l}\text { Negative uncertainty of corrected age } \\
\text { of the dated sample in years }\end{array}$ & Numeric & Positive decimal \\
\hline
\end{tabular}

Table S6: Characteristics of the lamina dating table

\begin{tabular}{|l|l|l|l|}
\hline Field & Description & Format & Constraints \\
\hline dating_lamina_id & Unique identifier for each lamina & Numeric & Positive integer \\
\hline entity_id & $\begin{array}{l}\text { Refers to the unique identifier for each } \\
\text { entity (as given in entity table) }\end{array}$ & Numeric & Positive integer \\
\hline depth_lam & $\begin{array}{l}\text { Depth of the midpoint of the lamina in } \\
\text { mm from a reference point }\end{array}$ & Numeric & Positive integer \\
\hline lam_thickness & Thickness in mm of the sample dated & Numeric & Positive decimal \\
\hline lam_age & Age in years of individual lamina & Numeric & None \\
\hline lam_age_uncert_pos & $\begin{array}{l}\text { Positive counting uncertainty of } \\
\text { individual lamina in years }\end{array}$ & Numeric & Positive decimal \\
\hline lam_age_uncert_neg & $\begin{array}{l}\text { Negative counting uncertainty of } \\
\text { individual lamina in years }\end{array}$ & Numeric & Positive decimal \\
\hline
\end{tabular}

Table S7: Characteristics of the hiatus place mark information table

\begin{tabular}{|l|l|l|l|}
\hline Field & Description & Format & Constraints \\
\hline sample_id & $\begin{array}{l}\text { Refers to the unique identifier for each sample (as } \\
\text { given in sample table) }\end{array}$ & Numeric & Positive integer \\
\hline hiatus & Indication of an hiatus & Text & $\begin{array}{l}\text { selected from } \\
\text { pre-defined list }\end{array}$ \\
\hline
\end{tabular}

Table S8: Characteristics of the gap place mark information table

\begin{tabular}{|l|l|l|l|}
\hline Field & Description & Format & Constraints \\
\hline sample_id & $\begin{array}{l}\text { Refers to the unique identifier for the sample (as } \\
\text { given in sample table) }\end{array}$ & Numeric & Positive integer \\
\hline gap & Indication of a gap & Text & $\begin{array}{l}\text { selected from } \\
\text { pre-defined list }\end{array}$ \\
\hline
\end{tabular}


Table S9: Characteristics of the original chronology information table

\begin{tabular}{|l|l|l|l|}
\hline Field & Description & Format & Constraints \\
\hline sample_id & $\begin{array}{l}\text { Refers to the unique identifier for the } \\
\text { sample (as given in sample table) }\end{array}$ & Numeric & Positive integer \\
\hline interp_age & Calendar age of the sample in years & Numeric & Positive decimal \\
\hline interp_age_uncert_pos & $\begin{array}{l}\text { Positive uncertainty on the age of the } \\
\text { sample in years }\end{array}$ & Numeric & Positive decimal \\
\hline interp_age_uncert_neg & $\begin{array}{l}\text { Negative uncertainty on the age of the } \\
\text { sample in years }\end{array}$ & Numeric & Positive decimal \\
\hline age_model_type & $\begin{array}{l}\text { Description of the age model used in } \\
\text { the original publication }\end{array}$ & Text & $\begin{array}{l}\text { selected from } \\
\text { pre-defined list }\end{array}$ \\
\hline ann_lam_check & $\begin{array}{l}\text { Indication that verification that } \\
\text { laminae are annual, in cases where } \\
\text { lamina counting is used to construct } \\
\text { the age model }\end{array}$ & Text & $\begin{array}{l}\text { selected from } \\
\text { pre-defined list }\end{array}$ \\
\hline dep_rate_check & $\begin{array}{l}\text { Indication that verification of the } \\
\text { deposition rate has been made }\end{array}$ & Text & $\begin{array}{l}\text { selected from } \\
\text { pre-defined list }\end{array}$ \\
\hline
\end{tabular}

Table S10: Characteristics of the carbon isotope data table

\begin{tabular}{|l|l|l|l|}
\hline Field & Description & Format & Constraints \\
\hline sample_id & $\begin{array}{l}\text { Refers to the unique identifier for the } \\
\text { sample (as given in sample table) }\end{array}$ & Numeric & Positive integer \\
\hline d13C_measurement & Original $\delta^{13}$ C measurement & Numeric & None \\
\hline d13C_precision & $\begin{array}{l}\text { Laboratory precision on the } \delta^{13} \mathrm{C} \\
\text { measurement }\end{array}$ & Numeric & None \\
\hline iso_std & Description of isotopic standard used & Text & $\begin{array}{l}\text { selected from } \\
\text { pre-defined list }\end{array}$ \\
\hline
\end{tabular}

Table S11: Characteristics of the oxygen isotope data table

\begin{tabular}{|l|l|l|l|}
\hline Field & Description & Format & Constraints \\
\hline sample_id & $\begin{array}{l}\text { Refers to the unique identifier for the } \\
\text { sample (as given in sample table) }\end{array}$ & Numeric & Positive integer \\
\hline d18O_measurement & Original $\delta^{18}$ O measurement & Numeric & None \\
\hline d18O_precision & $\begin{array}{l}\text { Laboratory precision on the } \delta^{18} \mathrm{O} \\
\text { measurement }\end{array}$ & Numeric & None \\
\hline iso_std & Description of isotopic standard used & Text & $\begin{array}{l}\text { selected from } \\
\text { pre-defined list }\end{array}$ \\
\hline
\end{tabular}


Table S12: Characteristics of the publication information table

\begin{tabular}{|l|l|l|l|}
\hline Field & Description & Type & Constraints \\
\hline ref_id & Unique identifier for the reference & Numeric & Positive integer \\
\hline citation & Full citation for the original publication & Text & None \\
\hline publication_DOI & Digital Object Identifier (DOI) of publication & Text & None \\
\hline
\end{tabular}

Table S13: Characteristics of the link entity and publication information table

\begin{tabular}{|l|l|l|l|}
\hline Field & Description & Format & Constraints \\
\hline entity_id & $\begin{array}{l}\text { Refers to the unique identifier for the entity (as given } \\
\text { in entity table) }\end{array}$ & Numeric & Positive integer \\
\hline ref_id & $\begin{array}{l}\text { Refers to the unique identifier for the publication (as } \\
\text { given in the publication information table) }\end{array}$ & Numeric & Positive integer \\
\hline
\end{tabular}

Table S14: Characteristics of the link composite and entity table

\begin{tabular}{|l|l|l|l|}
\hline Field & Description & Format & Constraints \\
\hline composite_entity_id & $\begin{array}{l}\text { Refers to the unique identifier for a } \\
\text { composite entity (as given in entity table) }\end{array}$ & Numeric & Positive integer \\
\hline single_entity_id & $\begin{array}{l}\text { Refers to the unique identifier for each } \\
\text { single entity in the composite (as given in } \\
\text { entity table) }\end{array}$ & Numeric & Positive integer \\
\hline
\end{tabular}

Table 15: Characteristics of the notes table

\begin{tabular}{|l|l|l|l|}
\hline Field & Description & Format & Constraints \\
\hline site_id & $\begin{array}{l}\text { Refers to the unique identifier for each site (as given in } \\
\text { site table) }\end{array}$ & Numeric & Positive integer \\
\hline notes & Notes and additional information about the site & Text & None \\
\hline
\end{tabular}

